\title{
Anti-herpes virus activities of bioactive fraction and isolated pure constituent of Mallotus peltatus: an ethnomedicine from Andaman Islands
}

Paromita Bag ${ }^{1}$, Debprasad Chattopadhyay ${ }^{1 *}$, Hemanta Mukherjee ${ }^{1}$, Durbadal Ojha ${ }^{1}$, Nilanjan Mandal', Mamta Chawla Sarkar ${ }^{2}$, Tapan Chatterjee ${ }^{3}$, Gobardhan Das $^{4}$ and Sekhar Chakraborti, ${ }^{1,2}$

\begin{abstract}
Background: Viral infections, particularly the infections caused by herpes simplex virus (HSV), represent one of the most serious public health concerns globally because of their devastating impact. The aim of this study was to evaluate the antiviral potential of methanolic crude extract of an ethnomedicine Mallotus peltatus, its active fraction and pure compound, against HSV-1 F and HSV-2 G.

Result: The cytotoxicity ( $\mathrm{CC}_{50}$, the concentration of $50 \%$ cellular toxicity), antiviral effective concentration ( $E C_{50}$, the concentration required to achieve $50 \%$ protection against virus-induced cytopathic effect), plaque reduction and the selectivity index (SI, the ratio of $\mathrm{CC}_{50}$ and $\mathrm{EC}_{50}$ ) was determined. Results showed that the crude methanolic extract of M. peltatus possessed weak anti-HSV activity. In contrast, the active fraction A and isolated ursolic acid from fraction A exhibited potent antiherpesvirus activity against both HSV-1 ( $E C_{50}=7.8$ and $5.5 \mu \mathrm{g} / \mathrm{ml} ; \mathrm{SI}=22.3$ and 20) and HSV-2 ( $E C_{50}=8.2$ and $5.8 \mu \mathrm{g} / \mathrm{ml}$, and $\mathrm{SI}=21.2$ and 18.97). The fraction $\mathrm{A}$ and isolated ursolic acid $(10 \mu \mathrm{g} / \mathrm{ml})$ inhibited plaque formation of HSV-1 and HSV-2 at more than $80 \%$ levels, with a dose dependent antiviral activity, compared to acyclovir. The time response study revealed that the anti-HSV activity of fraction A and isolated ursolic acid is highest at $2-5 \mathrm{~h}$ post-infection. Moreover, the time kinetics study by indirect immunofluorescence assay showed a characteristic pattern of small foci of single fluorescent cells in fraction A-treated virus infected cells at $2 \mathrm{~h}$ and $4 \mathrm{~h}$ post-infection, suggesting drug inhibited viral dissemination. Further, the PCR study with infected cell cultures treated with fraction $\mathrm{A}$ and isolated ursolic acid at various time intervals, failed to show amplification at 48-72 h, like acyclovir treated HSV-infected cells. Moreover, fraction A or isolated ursolic acid showed no interaction in combination with acyclovir.
\end{abstract}

Conclusion: This study revealed that bioactive fraction A and isolated ursolic acid of $M$. peltatus has good anti-HSV activity, probably by inhibiting the early stage of multiplication (post-infection of $0-5 \mathrm{~h}$ ), with SI value of 20, suggesting its potential use as anti-HSV agents.

Keywords: Mallotus peltatus, Ethnomedicine, Antiviral activity, Herpes simplex virus, Ursolic acid

\footnotetext{
* Correspondence: debprasadc@yahoo.co.in

${ }^{1}$ ICMR Virus Unit, ID \& BG Hospital, General Block 4, First floor, 57 Dr Suresh

Chandra Banerjee Road, Beliaghata, Kolkata 700010, India

Full list of author information is available at the end of the article
} 


\section{Introduction}

Herpes simplex viruses (HSV) are a common human pathogen that causes herpes labiles, herpes genitalis, keratitis and encephalitis. The HSV infection caused by type-1 (HSV-1) and type-2 (HSV-2) is mainly transmitted by close personal contact, and the virus can establishes lifelong latent infection in sensory neurons with recurrent lesions [1]. Herpes genitalis, usually caused by HSV-2, spread silently through sex, wreaks enormous financial and emotional damage due to its silent epidemic potential, and can cause life threatening infection in immunocompromised people and neonates [2]. Moreover, HSV-2 is a high risk factor for acquisition of HIV infection [3,4] and there is a synergistic relationship between HIV and HSV [5-7]. A recent study showed that HSV-suppressive therapy greatly reduced genital and plasma HIV-1 RNA levels in co-infected patients [8]. Hence, the risk of acquiring or transmitting HIV infection can be greatly decreased by reducing the spread of genital herpes.

Extensive and long term clinical use of antiherpesvirus agents like acyclovir, and its derivatives ganciclovir, foscarnet results severe side effects and drug-resistant viruses [9-11]. Further, acyclovir is reported to incorporate into the cellular DNA, yielding adverse drug reactions and thus, unsuitable for pregnant women [12] and neonates [13,14]. Moreover, the major determinants of effective immunity against HSV infection is not yet identified [15], and animal efficacy has not predicted success in humans [16]. Furthermore, the therapeutic vaccines failed to induce antibody-specific responses to protect recipients from recurrences [15]. Therefore, there is an unmated and urgent need for cheap, readily available, less toxic alternate agents to control and prevent HSV infection and its transmission. Ethnomedicinal plants offer a potential alternative because of their wide use in folklore medicine and some have promising therapeutic potential [17].

One of the widely used folklore medicine Mallotus peltatus (Geist) Muell. Arg. (Euphorbiaceae), known as Pataque and Obottacke by Onge and Kamala by local people, is a panatropical shrub endemic to the inland forests of Chidiyatappu, Baratang, Jarawa Creek, and Interview Islands of Andamans. The decoction of $M$. peltatus leaves is widely used among the tribal populations of Bay Islands, India, to treat skin and intestinal ailments [18], and stomachache [19]. However, till date there is no scientific validation of the use of this ethnomedicine. As our ongoing effort to identify potential therapeutic lead from ethnomedicinal source we have evaluated several ethnomedicines including M. peltatus for antimicrobial [20], antiinflammatory and related activities [20-22]. Based on traditional use in skin infections the aim of the present work is to evaluate, for the first time, the in vitro antiviral activity of the crude methanolic extract, most active fraction, and the isolated compound(s) from the active fraction of $M$. peltatus leaf.

\section{Materials and methods \\ Plant materials}

The leaves of $M$. peltatus (Geist.) Muell. Arg. was collected from the rain forests of Middle and Southern Andaman (Chidiyatappu, Baratang and Jaroaw Creek), India, throughout the year. The voucher specimens were identified by Dr. Sreekumar, Senior Scientist, Botanical Survey of India (BSI), and deposited in the Herbarium Section (Herbarium No. 9221) of the BSI, Andaman and Nicobar Circle, Port Blair, for future reference. The leaves were separately dried in shade, pulverized by a mechanical grinder and passed through 40-mesh sieve to get the fine powder.

\section{Preparation of extracts}

Coarsely powdered dry leaves (980 g) were extracted with 95\% methanol for $72 \mathrm{~h}$ at room temperature [23]. The whole extract was collected, filtered, and solvent evaporated to dryness under reduced pressure in a Eyela Rotary Evaporator (Japan) at $40-45^{\circ} \mathrm{C}$. The concentrated extract was aliquoted in amber-coloured bottles and kept in dessicator for further use. The w/w yield of the prepared extract was $8.7 \pm 0.21$.

\section{Phytochemical screening and chemical isolation}

The preliminary phytochemical tests of the crude methanolic extract were done by the method of Pollock and Stevens [24]. The concentrated crude methanolic extracts $(40 \mathrm{~g})$ were partitioned between $n$-butanol and water, while the aqueous part was lyophilized to dryness $(\approx 32 \mathrm{~g})$ and the solvent part was removed under reduced pressure in a rotary evaporator at $45^{\circ} \mathrm{C}$. The $n$ butanol fraction, weighing $\approx 35 \mathrm{~g}$, was then purified on silica gel (60-120 mesh, SRL) by column chromatography, and eluted with petroleum ether (PE): $\mathrm{PE}: \mathrm{CHCl}_{3}$ mixture (at different ratio) $\mathrm{CHCl}_{3}, \mathrm{CHCl}_{3}: \mathrm{MeOH}$ mixture (at different ratios) and $\mathrm{MeOH}$. All the eluted fractions were monitored by thin-layer chromatography (TLC) using pre-coated aluminium plates (E. Merck, Germany). Two major condensed fractions $\mathrm{A}$ and $\mathrm{B}$ were isolated along with a mixture of minor compounds in TLC. The isolated major compound(s) were then purified by repeated silica gel column chromatography and were eluted by PE: $\mathrm{CHCl}_{3}(1: 1)$ and $\mathrm{CHCl}_{3}: \mathrm{MeOH}$ (95:5) mixture to get the pure compound. The spectral analysis of isolated compounds from fraction A and B were done by IR (JASCO-FTIR spectrophotometer in potassium bromide discs), Mass (JEOL JMS600 Mass Spectrometer) and NMR (Bruker DPX-300 NMR 
spectrometer in DMSO- $\mathrm{d}_{6}$ solution). The identification was also done by Co-TLC, and superimposable IR with authentic samples. Melting points were checked in a melting point apparatus by mixed samples, i.e. authentic and isolated ursolic acid and $\beta$-sitosterol $[20,23]$.

\section{Viruses and the cell line}

African green monkey kidney cells (Vero cells, ATCC, Manassas, VA, USA) was grown and maintained in Eagle's minimum essential medium (EMEM), supplemented with $5-10 \%$ fetal bovine serum (FBS) [25]. The standard strain HSV-2 G (ATCC-734) and HSV-1 F (ATCC-733), purchased from the ATCC, were used. After plaque purification, the virus was grown and the virus stocks were stored at $-80^{\circ} \mathrm{C}$ for future use [26], and whenever required the virus stocks were grown on Vero cells to determine the titers and used for further study.

\section{Cytotoxicity assay}

Cell toxicity was monitored by determining the effect of the methanolic crude extract, its bioactive fraction A and isolated ursolic acid on cell morphology [27]. Vero cells was cultured onto 96 well plate at $1.0 \times 10^{5}$ cells $/ \mathrm{ml}$. Different concentrations of methanolic crude extract/ fraction $\mathrm{A} /$ isolated ursolic acid and standard drug acyclovir were added to each culture wells at a final volume of $100 \mu \mathrm{l}$, in triplicate, using DMSO $(0.1 \%)$ as a negative control. After incubation at $37^{\circ} \mathrm{C}$ with $5 \% \mathrm{CO}_{2}$ for 2 days, MTT reagent $(10 \mu \mathrm{l})$ was added to each well. After $4 \mathrm{~h}$ of incubation at $37^{\circ} \mathrm{C}$, the formazan was solubilized by adding diluted $\mathrm{HCl}(0.04 \mathrm{~N})$ in isopropanol, and the absorbance was read at $570 \mathrm{~nm}$ with a reference wavelength of $690 \mathrm{~nm}$ by an ELISA reader. Data were calculated as the percentage of cell viability using the formula: [(sample absorbance - cell free sample blank)/ mean media control absorbance)]/100\%. The $50 \%$ cytotoxic concentration $\left(\mathrm{CC}_{50}\right)$ causing visible morphological changes in $50 \%$ of Vero cells with respect to cell control were determined $[26,28]$.

\section{Antiviral assay}

The antiviral activity of crude methanolic extract, fraction A and the isolated ursolic acid against HSV-1 and HSV-2 was evaluated by MTT assay [29]. Vero cells were seeded onto 96 well plates with a concentration of 1.0 $\mathrm{x} 10^{5} \mathrm{cells} / \mathrm{ml}$. After incubation at $37^{\circ} \mathrm{C}$ in $5 \% \mathrm{CO}_{2}$ for $6 \mathrm{~h}$, the virus $(0.5 \mathrm{MOI})$ was added and incubated for $1 \mathrm{~h}$. Different concentrations of crude methanolic extract/fraction $\mathrm{A} /$ isolated ursolic acid were added to culture wells in triplicate at a final volume of $100 \mu \mathrm{l}$ in each well. The maximum concentration of DMSO $(0.1 \%)$ was used as negative control and acyclovir as positive control throughout the study. After 3 days incubation at $37^{\circ} \mathrm{C}$ in
$5 \% \mathrm{CO}_{2}$, the MTT test was carried out as described above. Viral inhibition rate was calculated as: $\left[\left(\mathrm{A}_{\mathrm{tv}}-\mathrm{A}_{\mathrm{cv}}\right) /\right.$ $\left.\left(\mathrm{A}_{\mathrm{cd}}-\mathrm{A}_{\mathrm{cv}}\right)\right] / 100 \% . \mathrm{A}_{\mathrm{tv}}$ indicates the absorbance of the crude methanolic extract/fraction A/ursolic acid with virus-infected cells. $A_{c v}$ and $A_{c d}$ indicate the absorbance of the virus control and the absorbance of the cell control. The antiviral concentration of $50 \%$ effectiveness $\left(\mathrm{EC}_{50}\right)$ was defined as the concentration which achieved $50 \%$ inhibition of virus-induced cytopathic effects. The amount of virus used in each experiment was based on infected target cells of $0.5 \mathrm{MOI}$ for both the viruses to produce $50 \%$ MTT formazan products as in uninfected control cells [30].

\section{Dose-response assay}

To analyze the dose-dependent effect of the test drugs on infected Vero cells, different concentrations of fraction A or isolated ursolic acid was added to HSV-1 and HSV-2 infected Vero cell culture in triplicate. After 2-3 days MTT assay was carried out to determine the inhibition of infection caused by the HSV, as described previously $[30,31]$.

\section{Viral plaque assay}

Plaque reduction assay was used to evaluate the antiviral activity of fraction A or isolated ursolic acid and to compare its activity with acyclovir. This assay evaluated the efficacy of the test agent on inhibition of infection of Vero cells by the free virus particles and thereby the number of viral plaques formed in cell monolayer, as every viral particle non-neutralized by the test agent will infect the cells and formed a plaque. Serial dilutions of fraction A or isolated ursolic acid in EMEM was added to the infected cells (MOI: 0.5 of HSV-1 or HSV-2) and incubated at room temperature, prior to the addition to cells. After $1-2 \mathrm{~h}$ incubation at $37^{\circ} \mathrm{C}$, the cells were washed with fresh EMEM and overlaid with methylcellulose, so the virus can spread via cell-to-cell route to form plaques. The plaques that developed after 2-3 days of incubation were stained with crystal violet. The effective concentration of fraction $\mathrm{A} /$ isolated ursolic acid that inhibited the number of viral plaques by $50 \%\left(\mathrm{EC}_{50}\right)$ was interpolated from the dose-response curves $[30,31]$.

\section{Time response assay}

Time response assay was used to investigate the mechanism of inhibition of the infection of HSV by fraction $\mathrm{A} /$ isolated ursolic acid at various time periods up to $24 \mathrm{~h}$. Vero cells at $1.0 \times 10^{5}$ cells $/ \mathrm{ml}$ were grown onto 96 well plates at $37^{\circ} \mathrm{C}$ in $5 \% \mathrm{CO}_{2}$. Following three different approaches the virus (0.5 MOI) was exposed to the different concentrations of the fraction A or isolated ursolic acid before infecting the vero cell (pre-infection); during infection of Vero cell (co-infection); and after the 
Vero cell culture was infected with the virus (post-infection) in different time interval, in triplicate, using DMSO $(0.1 \%)$ and acyclovir as a negative and positive control respectively. After incubation at $37^{\circ} \mathrm{C}$ in $5 \% \mathrm{CO}_{2}$ for $2-$ 3 days, the MTT test was carried out as described previously [31].

\section{Immunofluorescence (IFA) study of fraction A treated HSV infected cells}

HSV-infected Vero cells monolayer treated with different concentrations of fraction A was washed twice with phosphate buffered saline (PBS, $\mathrm{pH}$ 7.2) to remove the cell debris. The cells were then fixed with paraformaldehyde $(4 \%)$ and blocked with $1 \%$ bovine serum albumin (BSA) in 0.1\% PBS-triton X100 solution. The cells were washed with PBS, and then permeabilized with $0.1 \%$ triton X100 in PBS, and incubated overnight with FITC-labelled anti-HSV-1 mouse monoclonal antibodies (Dako Cytomation, Denmark). After washing with PBS, secondary rabbit polyclonal antibodies (Dako Cytomation, Denmark) and DAPI were added, and the cells were observed under epifluorescence microscope [32].

\section{Amplification of viral DNA isolated from the infected cells treated with fraction A/isolated ursolic acid by PCR}

HSV-1 infected Vero cell cultures, treated with fraction $\mathrm{A}$ /isolated ursolic acid at various time intervals $(0,48,72 \mathrm{~h})$ were harvested. Viral DNA extracted from the tissue culture fluid using QIAmp MiniElute Virus Spin Kit (Qiagen GmbH, Hilden, Germany), was subjected to PCR using HSV-1 type specific primers [33].

\section{Drug- plant extracts interaction}

The antiviral activity of fraction A or isolated ursolic acid, in combination with acyclovir, was evaluated against HSV-1 and HSV-2 (MOI 0.5) by MTT assay, with an aim to know whether this combination can increase the antiviral efficacy. The combined effect of acyclovir and fraction A or isolated ursolic acid on HSV1 replication was analyzed by isobologram method [3436]. Here, the $\mathrm{EC}_{50}$ was used to calculate the fractional inhibitory concentration (FIC) of the agents in combination. The interaction between fraction $\mathrm{A}$ or isolated ursolic acid and acyclovir was interpreted according to the combined FIC index $\left[\mathrm{FIC}_{\text {extract/compound }}+\mathrm{FIC}_{\text {acyclovir }}\right]$ as synergy $(\leq 0.5)$, no interaction $(0.5-4)$ or antagonism $(>4)$ [37].

\section{Statistical analysis}

The selective index (SI), a marker of antiviral activity, was determined as the ratio of $\mathrm{CC}_{50}$ to $\mathrm{EC}_{50}$. The statistically different effects of crude methanolic extract/ fraction A or isolated ursolic acid and acyclovir on the inhibition of HSV were compared with the control group as well as between fraction A or isolated ursolic acid, using Student's $t$-test. While the dose-dependent effect of antiviral activity was determined by linear regression.

\section{Results \\ Spectral analysis of isolated compounds from fraction A and fraction $B$}

The spectral data (IR, Mass and NMR) and melting points of isolated compounds from fraction $\mathrm{A}$ and B were identical with ursolic acid and $\beta$-sitosterol, respectively. The IR spectra of the isolated compound from fraction A (Figure 1A) agreed well with the authentic sample of ursolic acid (Figure 1B). The spectrum showed absorption band at 3458 and $1696 \mathrm{~cm}^{-1}$ indicating the presence of hydroxyl and carboxyl groups; while the band at 1033 and $996 \mathrm{~cm}^{-1}$ indicated $-\mathrm{C}-\mathrm{OH}$ bond, and another peak at $2929 \mathrm{~cm}^{-1}$ arises from the $\mathrm{C}-\mathrm{H}$ bonds.

The ${ }^{1} H N M R$ spectrum of the isolated compound from fraction $A$ in $D M S O-d_{6}$, showed the signal at 11.92 indicating a $-\mathrm{COOH}$ group at $28^{\text {th }}$ position. While the signal at $\delta 3.3$ agrees with the presence of $-\mathrm{CH}-\mathrm{OH}$ at $3^{\text {rd }}$ position, and $-\mathrm{OH}$ at $\delta 4.29$ peak. Signal at $\delta 5.12$ signifies the presence of a trisubstituted double bond (unsaturation) and the seven $-\mathrm{CH}_{3}$ groups between $\delta 0.6$ and 1.3. The shift positions of the isolated compound were almost identical with the authentic sample of ursolic acid (Figure 1C, 1D). The mass spectra of the compound isolated from fraction A showed prominent peak at $m l z$ 248, and other peaks at $m l z$ 207, 203 and 189 indicated the compound to be ursolic acid (Figure 1E). The melting point of isolated compound is $285-287^{\circ} \mathrm{C}$, similar to the authentic sample of ursolic acid.

The IR spectrum of the isolated compound from fraction B shows absorption bands at 3426 and $1056 \mathrm{~cm}^{-1}$ indicating the presence of $-\mathrm{OH}$ group. Other prominent peaks were at 2935, 2852, 1706 and $1462 \mathrm{~cm}^{-1}$ arising from the hydrocarbon skeleton. The absorption band at 965 and $802 \mathrm{~cm}^{-1}$ is due to $\mathrm{C}=\mathrm{C}-\mathrm{H}$ group (Figure 2A, 2B). The ${ }^{1} H N M R$ spectrum of the isolated compound from fraction $\mathrm{B}$ shows the shift at $\delta 3.53$, indicating $\mathrm{CH}-\mathrm{OH}$ group at $\mathrm{C} 3$ position. The olefinic proton at $6^{\text {th }}$ position has peak at $\delta 5.34$ and the six $-\mathrm{CH}_{3}$ group appeared between $\delta 0.6-1.03$ regions. Other protons appeared between $\delta 1.0$ - 2.3. The shift position indicated that the isolated compound was almost identical with the authentic sample of $\beta$-sitosterol (Figure 2C, $2 \mathrm{D})$. The mass spectra of isolated compound had the peak at $m l z$ 414 $(\mathrm{M}+)$ with significant fragment ion peaks at $m l z 396,382,273255,231$, and 213. The intense peak with highest mass number at $\mathrm{mlz} 414$ is due to parent molecular ion $\beta$-sitosterol (Figure 2E). A 

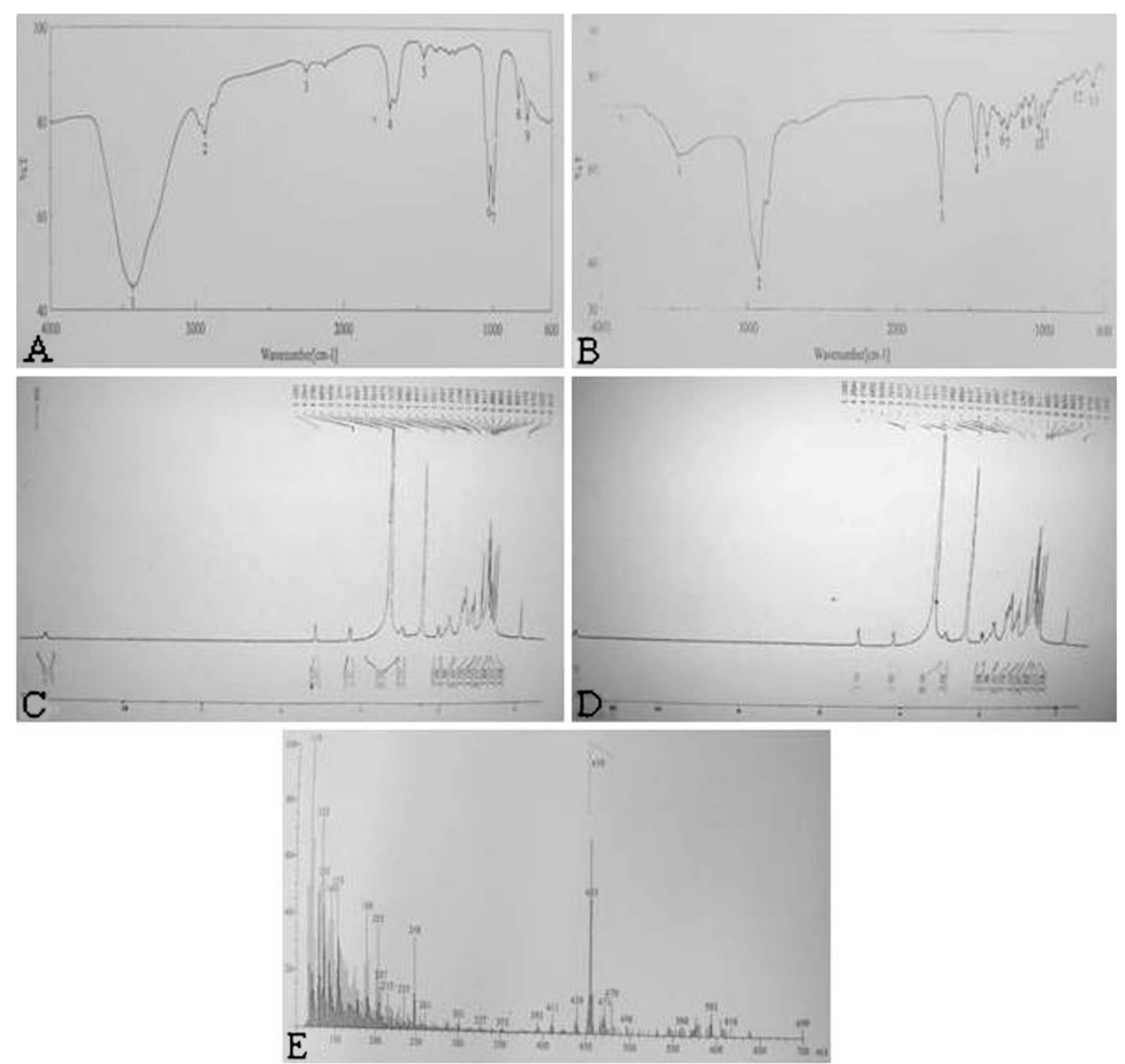

Figure 1 IR, ${ }^{1}$ HNMR and Mass Spectra of isolated compound from fraction A with authentic ursolic acid. The concentrated crude methanolic extract was partitioned between $n$-butanol and water. The aqueous part was lyophilized while the solvent part was evaporated by Eyela (Uni trap UT 1000, Japan) rotary evaporator at $45^{\circ} \mathrm{C}$. The $n$-butanol fraction was purified on silica gel column, and eluted with $\mathrm{PE}$ : $\mathrm{PE}$ : $\mathrm{CHCl}_{3,}$ $\mathrm{CHCl}_{3}: \mathrm{MeOH}$ and $\mathrm{MeOH}$. The eluted fractions, monitored by TLC, yielded two major condensed fractions $\mathbf{A}$ and $\mathbf{B}$. The isolated compound(s) from fraction $\mathbf{A}$ was then purified by repeated silica gel column and eluted with $\mathrm{PE}: \mathrm{CHCl}_{3}(1: 1)$ and $\mathrm{CHCl}_{3}: \mathrm{MeOH}(95: 5)$ mixture to obtain pure compound. The IR spectra of isolated compounds from fraction $\mathbf{A}$ done by JASCO-FTIR spectrophotometer in potassium bromide discs [A] agreed well with the authentic sample of ursolic acid [B]. The ${ }^{1} \mathrm{HNMR}$ spectrum of isolated compound from fraction $\mathbf{A}$ by Bruker DPX-300 NMR spectrometer in DMSO- $\mathrm{d}_{6}$ solution $[\mathbf{C}]$ indicated that the isolated compound was almost identical with the authentic sample of ursolic acid [D]. The Mass spectra of isolated compound from fraction A, determined by JEOL JMS600 Mass Spectrometer [E] indicated the compound to be ursolic acid.

less intense peak at $\mathrm{mlz} 400$ signifies the presence of its lower homologue (campesterol) in small amount. The melting point for isolated compound was 136$137^{\circ} \mathrm{C}$, similar to $\beta$-sitosterol authentic sample.

\section{Assessment of cytotoxicity and anti-HSV activity by MTT assay on Vero cell}

The MTT assay was used to determine the toxicity of the tested agents. The results revealed that the crude methanolic extract of M. peltatus, its fraction A and isolated ursolic acid exhibited a cytotoxic effect on Vero cells at concentrations higher than their $\mathrm{EC}_{50}$. Results presented in Table 1 revealed that the $\mathrm{CC}_{50}$ of crude methanolic extract, fraction $\mathrm{A}$ and isolated ursolic acid were $452 \mu \mathrm{g} / \mathrm{ml}, 174 \mu \mathrm{g} / \mathrm{ml}$ and $110 \mu \mathrm{g} / \mathrm{ml}$ respectively. The anti-HSV activity tested by MTT assay showed that the crude methanolic extract, fraction A and the isolated ursolic acid had anti-HSV activity at different dose level, based on their $\mathrm{EC}_{50}$ value and selectivity index (SI). The $\mathrm{EC}_{50}$ of fraction $\mathrm{A}(7.8 \pm 1.6$ and $8.2 \pm 1.8)$, and isolated ursolic acid (5.5 \pm 0.54 and $5.8 \pm 1.1)$ against HSV-1 and HSV-2 revealed the strongest anti-HSV activity, compared to the crude methanolic extract $(\mathrm{p}<0.0001)$. Further, the $\mathrm{EC}_{50}$ and SI index indicated that fraction $\mathrm{A}$ and isolated ursolic acid was more active against HSV-1 than $\mathrm{HSV}-2$. On the otherhand, fraction $\mathrm{B}$ had $\mathrm{CC}_{50}$ and $\mathrm{EC}_{50}$ at higher concentration with very low SI index, indicating its inactiveness, compared to acyclovir (Table 1).

\section{Dose-effect of fraction A/ursolic acid}

To analyze the dose-dependent antiviral activity we used different concentrations of fraction $\mathrm{A}$, isolated 


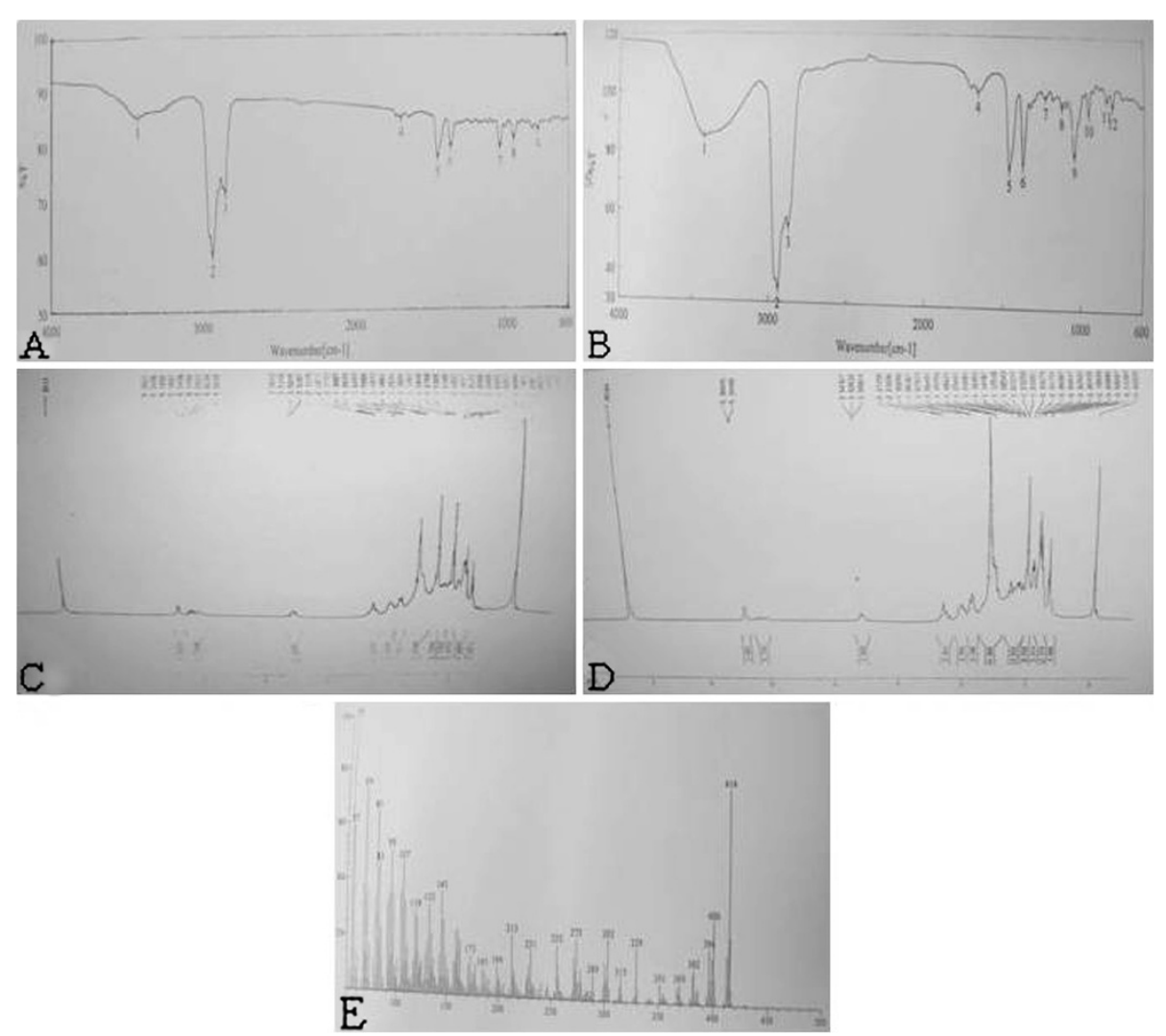

Figure 2 IR, ${ }^{1}$ HNMR and Mass Spectra of isolated compound from fraction B with authentic $\beta$-sitosterol. The concentrated crude methanolic extract was partitioned between $n$-butanol and water. The aqueous part was lyophilized while the solvent part was evaporated by Eyela (Uni trap UT 1000, Japan) rotary evaporator at $45^{\circ} \mathrm{C}$. The $n$-butanol fraction was purified on silica gel column, and eluted with PE: PE: $\mathrm{CHCl}_{3}$, $\mathrm{CHCl}_{3}: \mathrm{MeOH}$ and $\mathrm{MeOH}$. The eluted fractions, monitored by TLC, yielded two major condensed fractions $\mathbf{A}$ and $\mathbf{B}$. The isolated compound(s) from fraction $\mathbf{B}$ was then purified by repeated silica gel column and eluted with $\mathrm{PE}: \mathrm{CHCl}_{3}(1: 1)$ and $\mathrm{CHCl}_{3}$ : $\mathrm{MeOH}(95: 5)$ mixture to obtain pure compound. The IR spectra isolated compounds from fraction B done by JASCO-FTIR spectrophotometer in potassium bromide discs [A] agreed well with the authentic sample of $\beta$-sitosterol $[\mathbf{B}]$. The ${ }^{1} \mathrm{HNMR}$ spectrum of isolated compound from fraction $\mathrm{B}$ by Bruker DPX-300 NMR spectrometer in DMSO- $d_{6}$ solution $[\mathbf{C}]$ indicated that the isolated compound was almost identical with the authentic sample of $\beta$-sitosterol $[\mathbf{D}]$. The Mass spectra of isolated compound from fraction $\mathbf{B}$, determined by JEOL JMS600 Mass Spectrometer [E] indicated the compound is $\beta$ sitosterol.

ursolic acid, along with acyclovir and DMSO (0.1\%) as positive and negative control respectively, on HSV1 and HSV-2 infected Vero cells. The results presented in Figure 3A, showed that fraction $\mathrm{A}$ at
$14.5 \mu \mathrm{g} / \mathrm{ml}$ and isolated ursolic acid at $9.0 \mu \mathrm{g} / \mathrm{ml}$ exhibited nearly $100 \%$ inhibition against HSV-1. Similar effect was noticed with fraction A at $15 \mu \mathrm{g} / \mathrm{ml}$ and isolated ursolic acid at $12.5 \mu \mathrm{g} / \mathrm{ml}$ against $\mathrm{HSV}-2$

Table 1 Assessment of Anti-HSV activity of M. peltata crude methanolic extract and its constituents by MTT assay

\begin{tabular}{|c|c|c|c|c|c|}
\hline \multirow[t]{2}{*}{ Test drug } & \multirow[t]{2}{*}{$\mathrm{CC}_{50}^{\mathrm{a}}$} & \multicolumn{2}{|c|}{ HSV-1 F at MOI: 0.5} & \multicolumn{2}{|c|}{ HSV-2 G at MOI: 0.5} \\
\hline & & $\begin{array}{l}\text { Antiviral } \\
\text { activity } \\
\left(\mathrm{EC}_{50}^{\mathrm{b}}\right)\end{array}$ & $\begin{array}{l}\text { Selectivity } \\
\text { index (SI) }\end{array}$ & $\begin{array}{l}\text { Antiviral } \\
\text { activity } \\
\left(\mathrm{EC}_{50}^{\mathrm{b}}\right)\end{array}$ & $\begin{array}{l}\text { Selectivity } \\
\text { index (SI) }^{c}\end{array}$ \\
\hline Crude methanolic extract & 452 & $57.5 \pm 2.45$ & 7.86 & $61.2 \pm 3.1$ & 7.38 \\
\hline Fraction $\mathrm{A}$ & 174 & $7.8 \pm 1.6$ & 22.3 & $8.2 \pm 1.8$ & 21.21 \\
\hline Fraction B & 215 & $105.0 \pm 5.7$ & 2.04 & $120.0 \pm 7.2$ & 1.79 \\
\hline Ursolic acid (isolated) & 110 & $5.5 \pm 0.54$ & 20 & $5.8 \pm 1.1$ & 18.97 \\
\hline Acyclovir & 130 & $2.1 \pm 0.1$ & 61.9 & $2.9 \pm 0.1$ & 44.8 \\
\hline
\end{tabular}

${ }^{a}$ The $50 \%$ cytotoxic concentration for Vero cells in $\mu \mathrm{g} / \mathrm{ml}$.

${ }^{\mathrm{b}}$ Concentration of compound $(\mu \mathrm{g} / \mathrm{ml})$ producing $50 \%$ inhibition of virus induced CPE of three separate experiments.

${ }^{c}$ Selectivity index $(\mathrm{SI})=\mathrm{CC}_{50} / \mathrm{EC}_{50}$. 

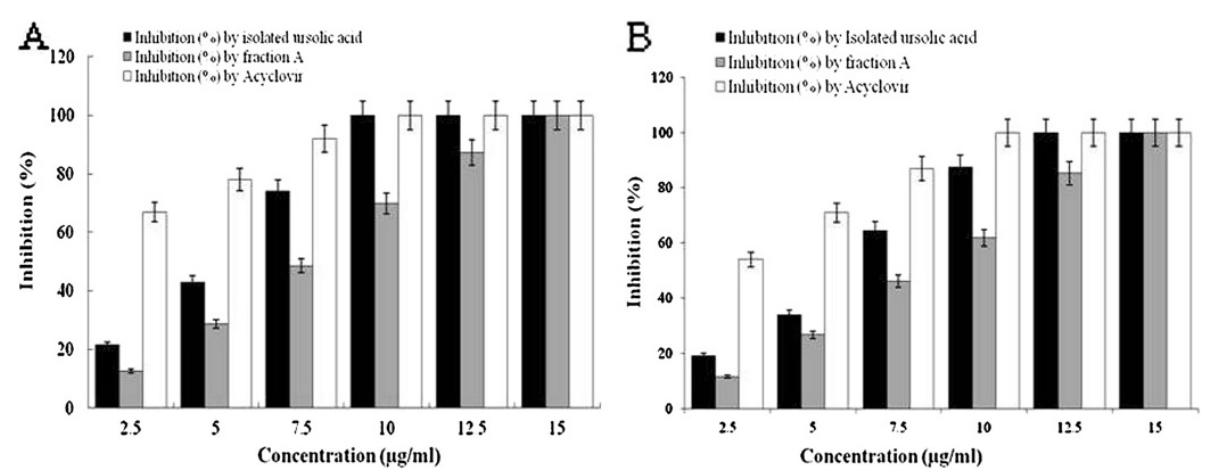

Figure 3 Dose dependent activity of isolated ursolic acid or fraction-A and acyclovir on HSV-1 [A] and HSV-2 [B]. Different concentrations of fraction $\mathbf{A}$, isolated ursolic acid or acyclovir $(2.5-15 \mu \mathrm{g} / \mathrm{ml}$ ) were added to HSV-1 and HSV-2 (black, grey and white bars) infected Vero cells after $1 \mathrm{~h}$ of infection. Inhibition percentage was evaluated by MTT assay after 3 days of incubation at $37^{\circ} \mathrm{C}$. Each bar represents the mean \pm S.E.M of three independent experiments.

(Figure 3B), indicating a high correlation between drug concentration and inhibition rate.

\section{Assessment of plaque reduction assay}

Plaque reduction assay was also used to access the antiviral activity of fraction A, and isolated ursolic acid, using acyclovir and DMSO (0.1\%) as positive and negative control respectively. The results revealed that both fraction $\mathrm{A}$ and isolated ursolic acid at a concentrations of $5-100 \mu \mathrm{g} / \mathrm{ml}$ inhibited plaque formation by HSV-1 and HSV-2, indicating their dose dependent inhibitory activity (Figure 4). The control drug acyclovir showed $100 \%$ inhibition of plaque formation at $10 \mu \mathrm{g} / \mathrm{ml}$, while no inhibition was noticed with $0.1 \%$ DMSO (data not shown).

Time course analysis of fraction A and or isolated ursolic acid

Time course analysis was performed with fraction A or isolated ursolic acid to investigate the mechanism of antiviral activity. Inhibition was evaluated by MTT assay after 3 days of infection and expressed as percentage inhibition. The result showed that fraction A at 7.8 and $14.5 \mu \mathrm{g} / \mathrm{ml}$ inhibited HSV-1 (Figure 5A) and HSV-2 (Figure 5B) significantly $(\mathrm{p}<0.001)$ within $2-5 \mathrm{~h}$ post-infection, i.e., during the early period of virus multiplication. Whereas no inhibition was found when the virus was exposed to fraction $\mathrm{A}$ or isolated ursolic acid before infection (pre-infection) or together (co-infection), upto the highest concentration tested.

\section{Immunofluorescence (IFA) study with fraction A treated HSV infected cells}

Indirect immunofluorescence assay was used to determine the kinetics of most active fraction $\mathrm{A}$ on antigen expression of HSV-1 F. The HSV-1 F infected Vero cells were treated with different concentrations of fraction $\mathrm{A}$ and incubated for different time intervals. The results revealed less number of virus particle in Vero
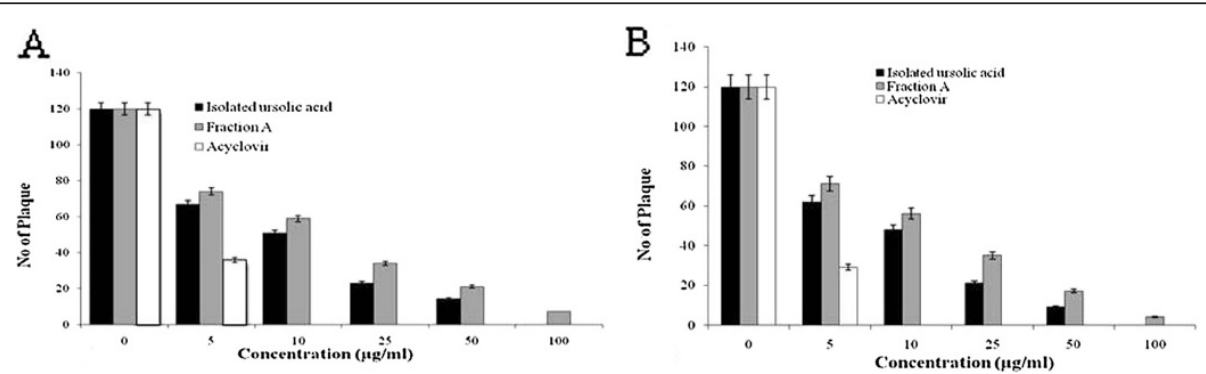

Figure 4 Plaque reduction assay of HSV-1[A] and HSV-2[B] with fraction A, isolated ursolic acid and acyclovir. Different concentrations of fraction A, isolated ursolic acid or acyclovir $(5-100 \mu \mathrm{g} / \mathrm{ml}$ ) were added to HSV-1 and HSV-2 (black, grey and white bars) infected Vero cells. After $1-2 \mathrm{~h}$ incubation at $37^{\circ} \mathrm{C}$ the cells were overlaid with methylcellulose and the plaques developed after $2-3$ days of incubation were stained with crystal violet. The plaque number inhibition was calculated, and the effective concentration of fraction A/isolated ursolic acid that inhibited the number of viral plaques was interpolated from the dose-response curve. 

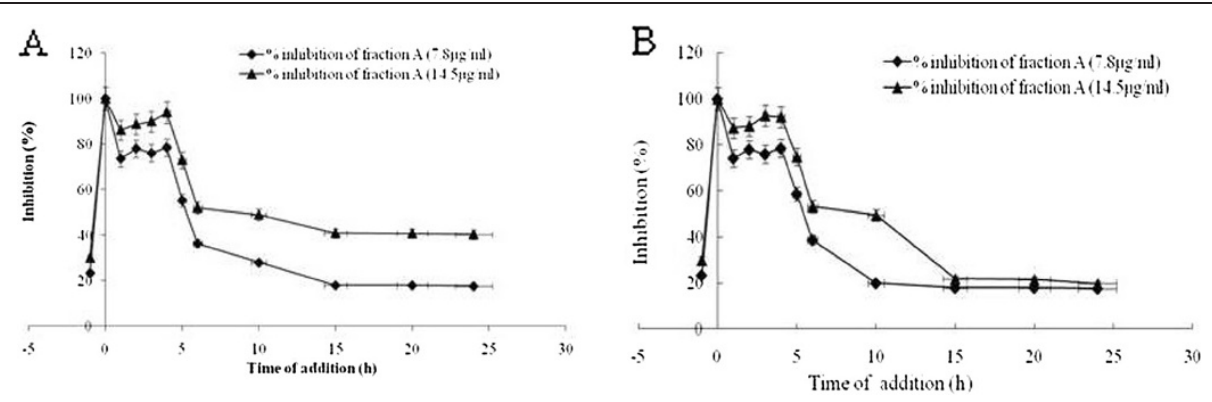

Figure 5 Inhibitory effect of fraction A during pre-infection, co-infection and post-infection on HSV-1 [A] and HSV-2 [B]. Different concentrations of fraction A [7.8 $\mu \mathrm{g} / \mathrm{ml}$ (square), and $14.5 \mu \mathrm{g} / \mathrm{ml}$ (triangle)] were added with the HSV-1 and HSV-2 infected Vero cells at various time period like pre-infection ( $-1 \mathrm{~h}$ ), co-infection ( $0 \mathrm{~h}$ ) or post-infection (1-24 h). After 3 days of incubation at $37^{\circ} \mathrm{C}$, inhibition was evaluated by MTT assay and expressed as the inhibition percentage. Each bar represents the mean \pm S.E.M of three independent experiments.

cells treated with the fraction $\mathrm{A}$, indicating the strong anti-HSV activity. The HSV antigen expression showed a characteristic pattern of small foci of single fluorescent in fraction A treated HSV-1 infected cells at different time interval (2-4 h post-infection), suggesting drug inhibited viral dissemination (Figure 6). Moreover, the antiviral activity of fraction $\mathrm{A}$ is more evident at its highest concentration $(14.5 \mu \mathrm{g} / \mathrm{ml})$ tested.

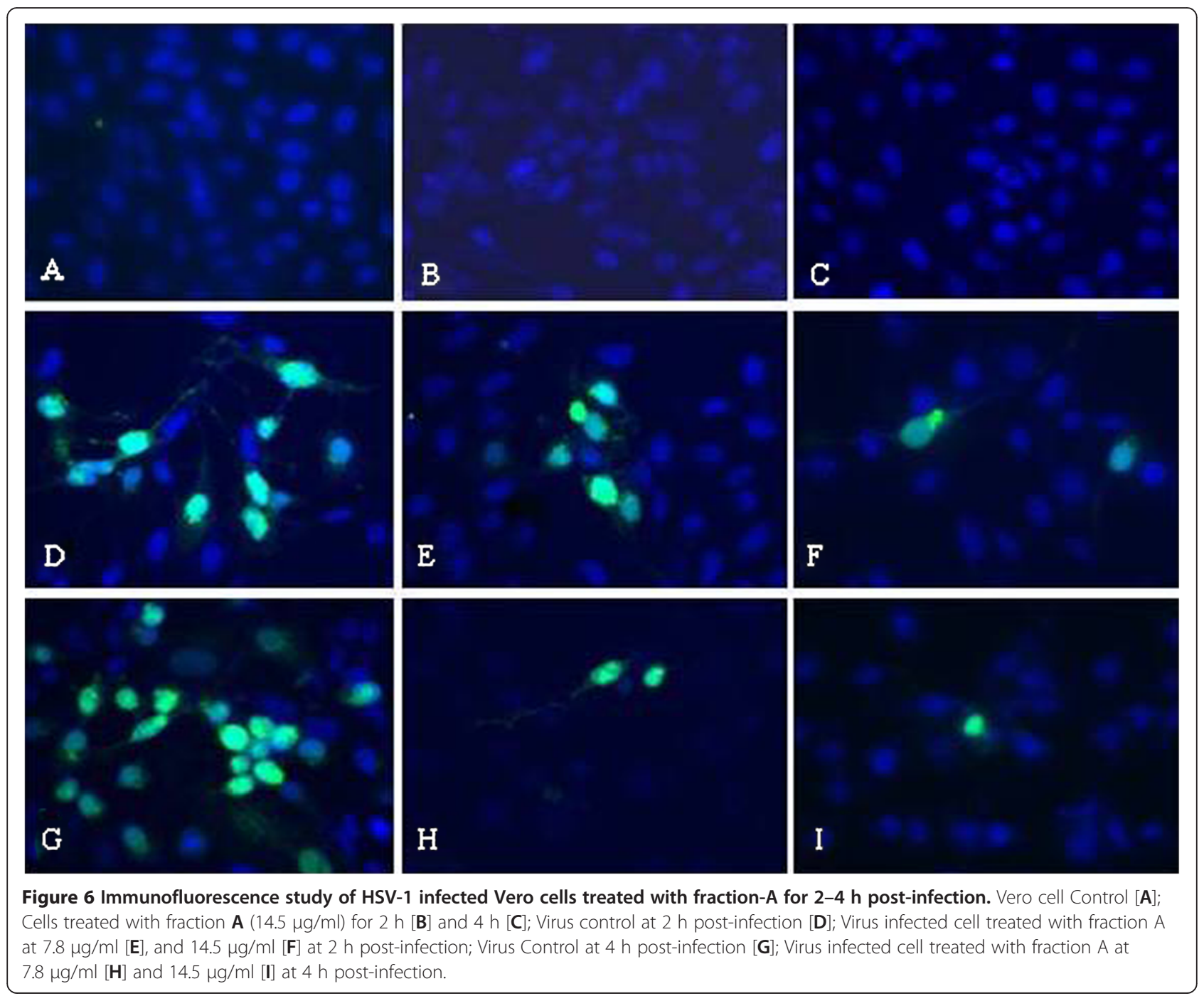




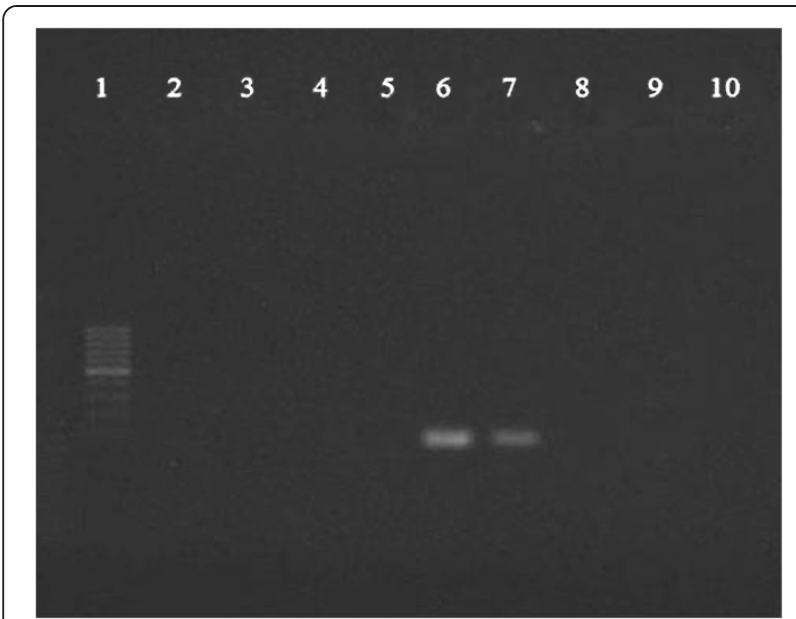

Figure 7 Detection of HSV-1 DNA in fraction A/ursolic acid or acyclovir-treated and untreated cultures by PCR. Lane 1: 100 bp Marker; Lane 2: PCR control; Lane 3: cell control; Lane 4:

cell + fraction A; Lane 5: cell + acyclovir; Lanes 6: positive control (HSV-1 after 72 h); Lane 7: cell + HSV-1 after 48 h; Lane 8: cell + HSV-1 (MOl: 0.5$)+$ fraction A $(14.5 \mu \mathrm{g} / \mathrm{ml})$; Lane 9: cell + HSV-1 (MOI: $0.5)+$ isolated ursolic acid $(9 \mu \mathrm{g} / \mathrm{ml})$; Lane 10: cell + HSV-1 (MOl: $0.5)+\operatorname{acyclovir}(5 \mu \mathrm{g} / \mathrm{ml})$.

\section{Amplification of viral DNA isolated from HSV-1 infected Vero cells treated with fraction A or isolated ursolic acid by PCR}

To compare the effect on viral replication, DNA amplification of HSV-infected and fraction A or isolated ursolic acid and acyclovir treated HSV-1 was detected by PCR. The results demonstrated that the fraction $\mathrm{A} /$ isolated ursolic acid treated HSV-1 (MOI 0.5) cultures at 24-72 h duration failed to show any amplification, similar to acyclovir (drug control) treated cultures. While HSV-1 infected culture (control) showed clear amplification of viral DNA in 1\% agarose gel at $48 \mathrm{~h}$ and $72 \mathrm{~h}$ (Figure 7). Furthermore, in infected cells, amplification of pol gene (internal control) indicated the integrity of the gene.

\section{Drug- plant extracts interaction}

To evaluate whether the fraction A and or isolated ursolic acid can able to increase the inhibitory efficacy of acyclovir in combination, we have tested the fraction A- acyclovir and isolated ursolic acid-acyclovir combination (synergism) by MTT assay, using isobologram method. Our results demonstrated that the $\mathrm{EC}_{50}$ of fraction $\mathrm{A}$, isolated ursolic acid and acyclovir was 7.8, 55 and $2.1 \mu \mathrm{g} / \mathrm{ml}$ respectively, but in combination with acyclovir the mean $\mathrm{EC}_{50}$ was 2.7 and $2.51 \mu \mathrm{g} / \mathrm{ml}$ respectively. Moreover, the FIC index of 0.78 (between acyclovir and fraction A) and 0.84 (between acyclovir and isolated ursolic acid), indicated that there was no synergistic interaction between them (Table 2). Furthermore, none of these combinations exhibited cytotoxic effect against Vero cell (data not shown).

\section{Discussion}

The present study for the first time, demonstrated the anti-HSV activity of crude methanolic extract of $M$. peltatus leaf, an ethnomedicine of Onge tribes of Andaman and Nicobar Islands, India. Phytochemical study revealed that the crude methanolic extract contain two major fractions, fraction $\mathrm{A}$ and $\mathrm{B}$, of which fraction A had significant anti-HSV activity. Chromatographic separation and spectral analysis revealed that fraction A contains a known triterpene ursolic acid, which possesses strong antiviral activity against HSV-1 and HSV-2 in vitro. The antiviral activity of the crude methanolic extract was weak compared to fraction A, probably due to its low concentrations of bioactive compound(s). While the higher antiviral activity of fraction $\mathrm{A}$, than the crude methanolic extract, is due to the higher concentration of bioactive compounds within the fraction. Earlier study with the crude methanolic extract of $M$. peltatus showed moderate antibacterial and antifungal [20], analgesic and antiinflammatory $[20,21,38]$ activity. On the otherhand fraction B do not showed any anti-HSV activity, hence not included in further study.

The cytotoxicity study revealed that the crude methanolic extract, fraction A and isolated ursolic acid had different $\mathrm{CC}_{50}$ due to the variable concentration of bioactive compound(s), and the antiviral activity was found far below the $\mathrm{CC}_{50}$ dose. Further, fraction $\mathrm{A}$ and isolated ursolic acid on both HSV-1 F and HSV-2 G revealed dose-dependent antiviral activity. Infection of

Table 2 Effects of fraction A/isolated ursolic acid in combination with acyclovir on HSV-1 F infected Vero cells

\begin{tabular}{lll}
\hline Fraction/Compound & ${\text { Mean } \mathbf{E C}_{\mathbf{5 0}} \pm \mathbf{S D}^{\mathbf{a}}}$ & FIC $_{\text {fraction/compound }}+$ FIC $_{\mathbf{a c y c l o v i r}}^{\mathbf{I n h i b i t o r y} \text { effect }}$ \\
\hline Fraction A & $7.8 \pm 1.6$ & - \\
\hline Ursolic acid (isolated) & $5.5 \pm 0.54$ & - \\
\hline Acyclovir alone & $2.1 \pm 0.1$ & - \\
\hline Acyclovir + Fraction A & $2.7 \pm 0.15$ & 0.84 \\
\hline Acyclovir + isolated ursolate & $2.51 \pm 0.12$ & 0.78 \\
\hline
\end{tabular}

${ }^{a}$ Results are the mean of three independent experiments of MTT assay.

${ }^{\mathrm{b}} \mathrm{FIC}_{\text {fraction/compound }}+\mathrm{FIC}_{\text {acyclovir }}$ are FICs of fraction/compound and acyclovir, respectively. 
Vero cell by HSV-1 and HSV-2 was significantly prevented by the fraction $\mathrm{A}$, or isolated ursolic acid with higher SI values. However, the $\mathrm{CC}_{50}$ of fraction $\mathrm{B}$ was just double the $\mathrm{EC}_{50}$, giving an insignificant $\mathrm{SI}$ for both HSV-1 and HSV-2.

The dose-dependent activity and time course analysis was done to understand how the fraction $\mathrm{A}$ and isolated ursolic acid inhibit the viral infection. Interestingly, fraction $\mathrm{A}$ and isolated ursolic acid was found to inhibit both HSV-1 and HSV-2 infection(s) in dose-dependent manner, with an $\mathrm{EC}_{50}$ of $7.8 \mu \mathrm{g} / \mathrm{ml}$ and $5.5 \mu \mathrm{g} / \mathrm{ml}$ for HSV-1 F and 8.2 and $5.8 \mu \mathrm{g} / \mathrm{ml}$ for HSV-2 G, respectively. However, $100 \%$ inhibition of HSV-1 was recorded at $14.5 \mu \mathrm{g} / \mathrm{ml}$ of fraction A and $9.0 \mu \mathrm{g} / \mathrm{ml}$ for isolated ursolic acid; while for HSV-2 it was $15 \mu \mathrm{g} / \mathrm{ml}$ of fraction A and $12.5 \mu \mathrm{g} / \mathrm{ml}$ of isolated ursolic acid. Results on the time-course effect between 0 and $5 \mathrm{~h}$ post-infection revealed that the fraction $\mathrm{A}$ and isolated ursolic acid possess a similar inhibitory effect. This suggests that the mode of action is not due to inhibition of vial adsorption, but inhibition of viral replication. The time response study, also demonstrated that both fraction A and isolated ursolic acid probably interfere early stage of HSV replication, as the maximum inhibition was noted at 2-5 $\mathrm{h}$ post-infection. However, the real antiviral mechanism of fraction A and isolated ursolic acid remains to be further elucidated.

The indirect immunofluorescence assay was carried out to determine the kinetics of fraction $\mathrm{A}$ on antigen expression of HSV-1. Maximum reduction in number of infected fluorescent cells was observed at $4 \mathrm{~h}$, along with a characteristic pattern of small foci of positive cells and even single fluorescent cells. This suggests that fraction A can inhibit viral dissemination. When fraction A was subsequently added at $2 \mathrm{~h}$ and $4 \mathrm{~h}$ time period, a significant reduction of positive fluorescent cells was observed (Figure 6). The non-amplification of fraction A treated HSV-1 infected cells by PCR further complemented and strengthened the antiviral activity of this plant. Detection and amplification of pol gene (control gene) in fraction A or isolated ursolic acid treated and virus infected cells (Figure 7) indicated that there was no cytotoxicity after treatment of cells with this plant product.

The widely used anti-herpes virus drug acyclovir is a nucleoside analogue, specifically targets the thymidine kinase of HSV [39]. However, its extensive and long term use yielded drug-resistant strains [9,11], due to mutations in viral thymidine kinase and/or DNA polymerase, that alter substrate sensitivity [40], and thus, become chromosome mutagen. Moreover, efficacy of therapeutic vaccines against primary and recurrent HSV infection has failed [15] and thus, search for natural alternative is the top priority to control and prevent HSV infections and its transmission. The earlier reports indicated that different species of Mallotus (M. philippinensis, M. japonicus, M. repandus) contain several secondary metabolites like terpenoids (mallotucin and malloripine), diterpenic lactones (mallotucin $\mathrm{B}, \mathrm{C}, \mathrm{D}$ ), triterpene alcohol (moretenol), saponins (crotoxigenin, coroglusagenine), cardinolipids, resins (rottlerine, isorottlerine), flavonoids, and $\beta$-sitosterol $[41,42]$. However, there were no reports on the bioactivity and phytochemistry of $M$. peltatus, except the isolation of ursolic acid and $\beta$-sitosterol alongwith some fatty acids by this group [20]. The ursolic acid is a pentacyclic amphiphilic triterpene with planner hydroxylated polycyclic [(3b)-3hydroxyurs-12-en-28-oic acid] structure, ubiquitous in medicinal plants as free acid or aglycones for triterpenoid saponins, and have been used since antiquity due to multiple bioactivities [21]. Contemporary research revealed that the ursolic acid, isolated from plants, is cytotoxic to some tumor and cancer cells [43-45], including skin tumor [46] and recommended for skin cancer therapy [47]. Other studies reported its antiviral [48], antibacterial [49], and potent anti-inflammatory [50-52] activities. It is a highly selective inhibitor of cyclic AMP-dependent protein kinase [53], human DNA polymerases and DNA topoisomerases [54] and has antioxidative [55] and apoptotic [56,57] activities. Ursolic acid isolated from Rosmarinus officinalis L. leaves is reported to inhibit the motility of Trypanosoma cruzi epimastigotes [58]; while ursolic acid isolated from Ocimum sanctum, $O$. basilicum and $O$. americanum showed anti-HSV activity with $\mathrm{ED}_{50}$ of $35-47 \mu \mathrm{g} / \mathrm{ml}$ by interfering at various steps of viral multiplication [59].

Thus, our results showed that fraction A, which contain ursolic acid as one of the compound, might be a potential therapeutic candidate against HSV infections, as indicated by its SI value $(7.86-22.3)$. Ursolic acid is known to be less toxic, can restore skin's collagen bundle and elasticity, and is dermatologically innocuous [60], while the antivirals presently used for herpes virus treatment have high toxicity, several side effects and problem of frequent drug resistance development. Therefore, our study demonstrated that the fraction $\mathrm{A}$ and its component(s) can serve as an alternative agent in herpes virus infection and thus, merit a greater attention.

\footnotetext{
Abbreviations

HSV: Herpes simplex virus; DMSO: Dimethyl sulfoxide; MOI: Multiplicity of infection; MTT: (3-(4,5-Dimethylthiazol-2-yl)-2,5-diphenyltetrazolium bromide; $\mathrm{HCl}$ : Hydrochloric acid; TCID: Tissue culture infective dose; $\mathrm{CC}_{50}$ : Cytotoxic concentration that is toxic to $50 \%$ cells; $\mathrm{EC}_{50}$ : Effective concentration required to achieve 50\% protection against virus-induced cytopathic effect; SI: Selectivity index; FIC: Fractional inhibitory concentration; CPE: Cytopathic effect.
}

Competing interests

The authors declare that they have no competing interests. 


\section{Acknowledgements}

Financial support by the Department of Biotechnology DBT), and Indian Council of Medical Research (ICMR), New Delhi, as research grant is highly acknowledged.

\section{Author details}

${ }^{1}$ ICMR Virus Unit, ID \& BG Hospital, General Block 4, First floor, 57 Dr Suresh Chandra Banerjee Road, Beliaghata, Kolkata 700010, India. ${ }^{2}$ Division of Virology, National Institute of Cholera \& Enteric Diseases, Kolkata, India. ${ }^{3}$ Department of Pharmaceutical Technology, Jadavpur University, Kolkata, India. ${ }^{4}$ Immunology Group, International Centre for Genetic Engineering and Biotechnology, New Delhi, India.

\section{Authors' contributions}

$\mathrm{PB}, \mathrm{HM}, \mathrm{DO}$, and NM contributed in lab work and DC in manuscript write up. MCS, and SC provided facility for some lab work, while TKC, GD help in some data analysis and technical details. DC was the principal investigator who planned and monitored the work and provided all the facilities to complete this work. All the authors read and approved the final manuscript.

\section{Authors' information}

Paromita Bag, Durbadal Ojha (M. Sc Microbiology), Nilanjan Mandal (M. Sc Biochemistry), Hemanta Mukherjee (M. Pharm, Clinical Pharmacy), Mamta Chawla Sarkar (PhD Zoology), Sekhar Chakraborti (PhD Biochemistry), Tapan Chatterjee (PhD Pharmacy), Gobardhan Das (PhD Immunology) and Debprasad Chattopadhyay (PhD Pharmaceutical Microbiology, and Assistant Director of ICMR Virus Unit, Kolkata).

Received: 1 November 2011 Accepted: 24 May 2012 Published: 24 May 2012

\section{References}

1. Barton S: The role of anti-HSV therapeutics in the HIV-infected host and in controlling the HIV epidemic. Herpes 2005, 12:15-22.

2. Fatahzadeh $M$, Schwartz RA: Human herpes simplex virus infections: epidemiology, pathogenesis, symptomatology, diagnosis, and management. J Am Acad Dermatol 2007, 57(5):737-763.

3. Cowan FM, French RS, Mayaud P, Gopal R, Robinson NJ, de Oliveira SA, Faillace T, Uusküla A, Nygård-Kibur M, Ramalingam S, Sridharan G, El Aouad R, Alami K, Rbai M, Sunil-Chandra NP, Brown DW: Seroepidemiological study of herpes simplex virus types 1 and 2 in Brazil, Estonia, India, Morocco, and Sri Lanka. Sex Transm Infect 2003, 79(4):286-290.

4. Safrin S, Crumpacker C, Chatis P, Davis R, Hafner R, Rush J, Kessler HA, Landry B, Mills J: A controlled trial comparing foscarnet with vidarabine for acyclovir-resistant mucocutaneous herpes simplex in the acquired immunodeficiency syndrome. The AIDS Clinical Trials Group. N Engl J Med 1991, 325(8):551-555.

5. White MK, Gorrill TS, Khalili K: Reciprocal transactivation between HIV-1 and other human viruses. Virology 2006, 352:1-13.

6. Wald A: Synergistic interactions between herpes simplex virus type-2 and human immunodeficiency virus epidemics. Herpes 2004, 11:70-76

7. Mbopi-Kéou FX, Grésenguet G, Mayaud P, Weiss HA, Gopal R, Matta M, Paul $J$, Brown DW, Hayes RJ, Mabey DC, Bélec L: Interactions between herpes simplex virus type 2 and human immunodeficiency virus type 1 infection in African women: opportunities for intervention. J Infect Dis 2000, 182(4):1090-1096.

8. Nagot $N$, Ouédraogo A, Foulongne $V$, Konaté I, Weiss HA, Vergne L, Defer M-C, Djagbaré SA, Andonaba J-B, Becquart P, Segondy M, Vallo R, Sawadogo A, Van de Perre P, Mayaud P: Reduction of HIV-1 RNA levels with therapy to suppress herpes simplex virus. N Engl J Med 2007, 356:790-799.

9. Morfin F, Thouvenot D: Herpes simplex virus resistance to antiviral drugs. J Clin Virol 2003, 26(1):29-37.

10. Reyes M, Shaik NS, Graber JM, Nisenbaum R, Wetherall NT, Fukuda K, Reeves WC: Task Force on Herpes Simplex Virus Resistance, Acyclovir-resistant genital herpes among persons attending sexually transmitted disease and human immunodeficiency virus clinics. Arch Intern Med 2003, 163(1):76-80.

11. Miserocchi E, Modorati G, Galli L, Rama P: Efficacy of valacyclovir vs acyclovir for the prevention of recurrent herpes simplex virus eye disease: a pilot study. Am J Ophthalmol 2007, 144(4):547-551.
12. Narayana K: A purine nucleoside analogue-acyclovir [9-(2-hydroxyethoxymethyl)-9 h-guanine] reversibly impairs testicular functions in mouse. J Toxicol Sci 2008, 33(1):61-70.

13. Brigden $D$, Rosling $A E$, Woods NC: Renal function after acyclovir intravenous injection. Am J Med 1982, 73(1A):182-185.

14. Sawyer MH, Webb DE, Balow JE, Straus SE: Acyclovir-induced renal failure Clinical course and histology. American J Med 1988, 84(6):1067-1071.

15. Stanberry LR: Clinical trials of prophylactic and therapeutic herpes simplex virus vaccines. Herpes 2004, 11(A):161-169.

16. Koelle DM: Vaccines for herpes simplex virus infections. Curr Opin Investig Drugs 2006, 7:136-141.

17. Chattopadhyay D, Khan MTH: Ethnomedicines and ethnomedicinal phytophores against Herpesviruses. Biotechnol Annu Rev 2008, 14:297-348.

18. Bhargava N: Ethnobotanical studies of the tribes of Andaman and Nicobar Islands India I Onge. Econ Bot 1983, 37:110-119.

19. Dagar HS, Dagar JC: Plant folk medicines among Nicobarese of Katchal Island, India. Econ Bot 1991, 45:114-119.

20. Chattopadhyay D, Arunachalam G, Mandal AB, Sur TK, Mandal SC, Bhattacharya SK: Antimicrobial and anti-inflammatory activity of Mallotus peltatus leaf extract. J Ethnopharmacol 2002, 82:229-237.

21. Chattopadhyay D, Arunachalam G, Sur TK, Bhattacharya SK, Mandal AB: Analgesic and Antiinflammatory Activity of Alstonia macrophylla and Mallotus peltatus leaf extracts: two popular ethnomedicines of Onge, a Negrito tribe of little Andaman. Oriental Pharm Exp Med 2005, 5(2):124-136.

22. Chattopadhyay D, Arunachalam G, Mandal AB, Bhattacharya SK: Pharmacological activities of three Ethnomedicines of Little Andaman. In Recent progress in Medicinal Plants, Search for natural Drugs, Volume Volume 13. Edited by Govil JN, Singh VK, Arunachalam C. Houston: Studium Press LLC; 2006:511-537.

23. Chattopadhyay D, Maiti K, Kundu AP, Chakrabarty MS, Bhadra R, Mandal SC, Mandal AB: Antimicrobial activity of Alstonia macrophylla: folklore of Bay Islands. J Ethnopharmacol 2001, 77:49-55.

24. Pollock JRA, Stevens R: Dictionary of Organic Compounds, Volume 5. 4th edition. London: Eyre and Spottiswoode; 1965.

25. Mindel A: Genital herpes-how much of a public-health problem? Lancet 1988, 351:16-18.

26. Hsiang CY, Hsieh CL, Wu SL, Lai IL, Ho TY: Inhibitory effect of anti-pyretic and anti-inflammatory herbs on herpes simplex virus replication. Am J Chin Med 2001, 29(3-4):459-467.

27. Wilson Anne P: Cytotoxicity and viability. In Animal Cell Culture: A Practical Approach, Volume 1. 3rd edition. Edited by Masters John RW. Oxford: Oxford University Press; 2000. Chapter 7. ISBN 978-0199637966.

28. Zhang Y, But P-H, Ooi E-CV, Xu H-Xi, Delaney GD, Lee Spencer HS, d Lee SF: Chemical properties, mode of action, and in vivo anti-herpes activities of a lignin-carbohydrate complex from Prunella vulgaris. Antiviral Research 2007, 75(3):242-249.

29. Mosmann T: Rapid colorimetric assay for cellular growth and survival: application to proliferation and cytotoxicity assays. J Immunol Methods 1983, 65(1-2):55-63.

30. Chattopadhyay D, Chawla Sarkar M, Chatterjee T, Dey R, Bag P, Chakrabarty S, Khan MTH: Recent advancements for the evaluation of Antiviral activities of natural products. New Biotechnology 2009, 25(5):347-368.

31. Chiang LC, Chiang W, Liu MC, Lin CC: In vitro antiviral activities of Caesapinia pulcherrima and its related flavonoids. J Antimicrob Chemother 2003, 52:194-198.

32. Villamil SM, Alche LE, Coto CE: Inhibition of herpes simplex virus type-1 multiplication by meliacine a peptide of plant origin. Antivir Chem Chemother 1995, 6:239-244.

33. Verma H, Patil PR, Kolhapure RM, Gopalkrishna V: Antiviral activity of the Indian medicinal plant extract, Swertia chirata against herpes simplex viruses: a study by in vitro and molecular approach. Indian J Med Microbiol 2008, 26(4):322-326.

34. Suhnel J: Evaluation of synergism or antagonism for the combined action of antiviral agents. Antiviral Res 1990, 13:23-39.

35. Lawetz C, Liuzzi M: The antiviral activity of the ribonucleotide reductase inhibitor BILD 1351 Se in combination with acyclovir against HSV type-1 in cell culture. Antiviral Res 1998, 39:35-46.

36. Piret J, Roy S, Gagnon M: Comparative study of mechanism of herpes simplex virus in activation by sodium lauryl sulphate and $n$ lauroylsarcosine. Antimicrob Agents Chemother 2002, 46:2933-2942. 
37. Cheng HY, Lin TC, Yang CM, Wang KC, Lin LT, Lin CC: Putranjivain A from Euphorbia jolkini inhibits both virus entry and late stage of replication of herpes simplex virus type 2 in vitro. J Antimicrob Chemother 2004, 53:577-583.

38. Chattopadhyay D, Arunachalam G, Mandal AB, Mandal SC: Evaluation of Antipyretic activity of leaf extracts of Mallotus peltatus (Geist) Muell. Arg.: A folk medicine. Phytomedicine 2002, 9:632-635.

39. Kleymann G: New antiviral drugs that target herpesvirus helicase primase enzymes. Herpes 2003, 10(2):46-52.

40. Sweetman S: In The complete drug reference. 34th ed. Edited by Martindale. London: Pharmaceutical Press; 2004:550-554. ISBN 0-85369.

41. Rastogi RP: Mallotus. In Compendium of Indian Medicinal Plants, Volume 3. New Delhi: Publications \& Informations Directorate, CSIR; 1992:450.

42. Sastri BN: Wealth of India, Raw Materials; Vol. 1A, 199-200. New Delhi: Publications \& Information Directorate, CSIR; 1985:1948-1976.

43. Yamagishi T, Zhang DC, Chang JJ: The cytotoxic principle of Hyptis capitata and structure of new triterpene hyptatica acid A and B. Phytochemistry 1988, 27(321):3-6.

44. Kim KW: Anticancer Activities of Plant Triterpenoids, Ursolic acid and Oleanoid acid. J Korean Assoc Cancer Prev 1997, 2:38-44.

45. Kim SH, Song GY, Ryu SY: Antitumor and antimetastatic activities of ursolic acid. Korean J Oriental Med Pathol 1999, 13:65-75.

46. Simon A, Delage C, Saux M, Chulia A, Najida A, Rigaud M: Structure of ursolic acid ethanol solvate. Acta Crystallogr C 1992, 48:726-728.

47. Muto $Y$, Ninomiya M, Fujiki $\mathrm{H}$ : Present status on cancer chemoprevention in Japan. Jpn J Clin Oncol 1990, 20:219-224.

48. Kashiwada Y, Wang HK, Nagao T: Anti-AIDS Agents. 30 anti-HIV activity of oleanolic acid. Promolic acid and structurally related triterpenoids. J Natural Product 1998, 61:1090-1095.

49. Kowalewski Z, Kortus M, Edzia W, Koniar H: Antibiotic action of ursolic acid. Arch Immunol et Ther Exp (Warsz) 1976, 24:115-119.

50. Arunachalam G, Chattopadhyay D, Mandal AB, Sur TK, Mandal SC: Evaluation of antiinflammatory activity of Alstonia macrophylla wall ex A. DC. Leaf extract. Phytomedicine 2002, 9:727-730

51. Najid A, Simon A, Cook J, Chable-Rabinobitch H, Delage C, Chulia A, Riguad $\mathrm{M}$ : Characterization of ursolic acid as a lipoxygenase and cyclooxygenase inhibitor using macrophages, platelets and differentiated HL60 leukemic cells. FEBS Lett 1992, 229:213-217.

52. Ringbom $T$, Segura $L$, Noreem $Y$, Perera $P$, Bohlin L: Ursolic acid from Plantago major, a selective inhibition of cyclooxygenase- 2 catalyzed prostaglandin biosynthesis. J Nat Prod 1998, 61:1212-1215.

53. Wang BH, Polya GM: Selective inhibition of cyclic AMP-Dependent protein kinase by amphiliphilic triterpenoids and related compounds. Phytochemistry 1996, 41:55-63.

54. Mizushina Y, lida A, Ohta K, Sugawara F, Sakaguchi K: Novel triterpenoids inhibit both DNA polymerase and DNA topoisomerase. Biochem J 2000, 350:757-763.

55. Kim JS, Huh Jl, Song SH: The antioxidative mechanism of ursolic acid. Korean J Gerontol 1996, 6:52-56.

56. Kim DK, Baek JH, Kang CM: Apoptotic activity of ursolic acid may correlate with the inhibition of DNA replication. Int J Cancer 2000, 87:629-636.

57. Choi YH, Baek JH, Yoo MA, Chung HY, Kim ND, Kim KW: Induction of apoptosis by ursolic acid through activation of caspases and downregulation of c-IAPs in human prostate epithelial cells. Int J Oncol 2000, 17:565-571.

58. Abe F, Yamauchi T, Nagao T, Kinjo J, Okabe H, Higo H, Akahane H: Ursolic acid as a trypanocidal constituent in rosemary. Biol Pharm Bull 2002, 25:1485-1487.

59. Yucharoen $R$, Anuchapreeda $S$, Tragoolpua $Y$ : Anti-herpes simplex virus activity of extracts from the culinary herbs Ocimum sanctum L., Ocimum basilicum L. and Ocimum americanum L. Afr J Biotechnol 2011, 10(5):860-866.

60. Katsuo M, Hiroki T, Norio F, Yasutomo N, Yukiko Y: Photoaging inhibitor and dermal agent for external use. 1997. Japanese Patent No. 09143050.

doi:10.1186/1743-422X-9-98

Cite this article as: Bag et al:: Anti-herpes virus activities of bioactive fraction and isolated pure constituent of Mallotus peltatus: an ethnomedicine from Andaman Islands. Virology Journal 2012 9:98.

\section{Submit your next manuscript to BioMed Central and take full advantage of:}

- Convenient online submission

- Thorough peer review

- No space constraints or color figure charges

- Immediate publication on acceptance

- Inclusion in PubMed, CAS, Scopus and Google Scholar

- Research which is freely available for redistribution 